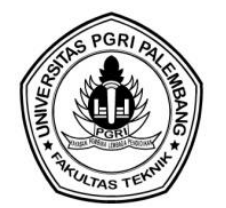

\title{
PENGARUH PENAMBAHAN SABUT KELAPA DAN ABU SEKAM PADI TERHADAP KUAT GESER TANAH
}

\author{
Arima Sefta, Adiguna*, Reffanda Kurniawan \\ Program Studi Teknik Sipil, Fakultas Teknik, Universitas PGRI Palembang \\ "Corresponding Author, email : adigunaym@gmail.com
}

\begin{abstract}
ABSTRAK
Tanah merupakan bagian terpenting bidang konstruksi teknik sipil karena hampir semua bangunan berdiri atau dibangun di atas tanah. Tanah lempung lunak adalah jenis tanah yang memiliki daya dukung rendah dan daya mampat yang tinggi serta memiliki indeks plastisitas yang tinggi membuat tanah ini mempunyai prilaku mengembang jika terkena air sehingga disebut tanah ekspansif. Salah satunya adalah tanah merah di daerah Pakjo. Oleh karena itu, perlu beberapa alternatif untuk tanah tersebut menjadi mempunyai daya dukung dan kuat geser yang lebih baik, di mana dalam penelitian ini menggunakan campuran sabut kelapa dan abu sekam padi sebagai bahan tambahannya. Dan penelitian ini bertujuan untuk mengetahui apakah campuran limbah sabut kelapa dan abu sekam padi dapat meningkatkan nilai kuat geser tanah merah melalui pengujian direct shear dengan persentanse penambahan sebesar 5\%,10\%, 15\%, 20\%, 25\% dengan skala laboratorium. Hasil pengujian tanah merah didapat kadar air $(\omega)$ sebesar $27,70 \%$, berat jenis tanah $\left(G_{s}\right)$ 2,67, batas cair $(L L)$ 63,35\%, batas plastis (PL) 25,13\%, dan indeks plastisitas (IP) 38,22\%, dengan sistem klasifikasi USCS berupa tanah lempung (CH),dan sistem klasifikasi AASHTO adalah A-7-6 (clavey soils). Hasil pengujian pemadatan tanah standar asli didapat kadar air optimum 24,20\% dan berat isi kering optimum 1,634 $\mathrm{gr} / \mathrm{cm}^{3}$. Hasil pengujian direct shear didapat kuat geser $(\tau)$ tertinggi terjadi pada tanah merah dicampur dengan sabut kelapa dan abu sekam padi sebanya 5\% yaitu 100,5 kPa dengan nilai kohesi (c) 20,75 kPa dan nilai sudut geser dalam ( $\phi$ ) 45,37,01
\end{abstract}

Kata Kunci : Tanah Lempung Lunak, Sabut Kelapa, Abu Sekam Padi, Soil Properties, Direct Shear

\begin{abstract}
Soil is the most important part of the field of civil engineering construction because almost all buildings stand or are built on the ground. Soft clay soil is a type of soil that has a low bearing capacity and high compressibility and has a high index of plasticity which makes this soil expand when exposed to water, so it is called expansive soil. One of them is the red soil in the Pakjo area. Therefore, several alternatives are needed for the soil to have better bearing capacity and shear strength, where in this study using a mixture of coconut husk and rice husk ash as an additional material. And this study aims to determine whether the mixture of coconut husk waste and rice husk ash can increase the value of the shear strength of red soil through direct shear testing with an additional percentage of $5 \%, 10 \%, 15 \%, 20 \%, 25 \%$ on a laboratory scale. The red soil test results obtained water content ( $\omega$ ) of $27.70 \%$, soil density (Gs) 2.67, liquid limit (LL) $63.35 \%$, plastic limit (PL) 25.13\%, and plasticity index (IP) $38.22 \%$, with the USCS classification system in the form of clay (CH), and the AASHTO classification system is A-7-6 (clavey soils). The results of the original standard soil compaction test obtained an optimum water content of $24.20 \%$ and an optimum dry weight of $1.634 \mathrm{~g} / \mathrm{cm} 3$. The results of the direct shear test showed that the highest shear strength $(\tau)$ occurred in red soil mixed with coconut husk and rice husk ash as much as 5\%, namely $100.5 \mathrm{kPa}$ with a cohesion value (c) of $20.75 \mathrm{kPa}$ and the value of the internal shear angle $(\phi) 45.37^{\circ}$
\end{abstract}

Keywords : Soft Clay, Coconut Coir, Rice Husk Ash, Soil Properties, Direct Shear

\section{PENDAHULUAN}

Tanah merupakan bagian terpenting dalam konstruksi teknik sipil, karena hampir semua bangunan berdiri atau dibangun di atas tanah. Tanah didefinisikan sebagai suatu bahan yang terdiri dari agregat (partikel) mineral padat dan bahan organik lapuk 
(partikel padat) yang tidak terikat satu sama lain (berikat secara kimia), disertai dengan cairan dan gas yang mengisi ruang. Ruang antar partikel padat tersebut (Das,1995). Tanah merah merupakan tipikal tanah sisa yang telah mengalami kondisi pelapukan dan pencucian. Jenis tanah ini disebut juga tanah laterite. Secara umum telah diketahui bahwa lempung merah memiliki sifat-sifat yang baik, antara lain kekuatan tinggi, kompresibilitas rendah, dan tidak akan memuai atau menyusut akibat perubahan kadar air (Utami, 2014). Tanah merah merupakan tanah sisa yang khas, setelah kondisi pelapukan dan leaching yang membuat tanah menjadi merah karena kandungan besi (Fe) dan alumina (Aloksida). Tanah Meraht juga bisa disebut sebagai laterit, yang hampir terdapat di sebagian besar wilayah Indonesia, terutama di daerah dengan iklim campuran kering dan basah yang dibentuk oleh batuan beku sedimen. (Jurnal ,2018). Tanah liat adalah agregat partikel mikroskopis dan submikroskopik yang dihasilkan oleh dekomposisi kimia unsur penyusun batuan, dan bersifat plastis pada kadar air sedang hingga luas. Sangat keras dalam keadaan kering, tidak mudah terkelupas dengan jari, dan permeabilitas tanah liat sangat rendah (Rustam, dkk, 2020).

Sistem klasifikasi tanah adalah suatu sistem klasifikasi yang sistematik yang membagi jenis tanah dengan sifat yang sama ke dalam kelompok dan subkelompok sesuai dengan kegunaannya. Sistem klasifikasi tanah yang digunakan didasarkan pada sistem klasifikasi tanah USCS dan AASHTO (Jimmyanto, 2014). Menurut Das, (2008), kuat geser tanah adalah gaya dengan fungsi menahan tanah agar tidak terjadi keruntuhan, dimana kekuatan geser massa tanah merupakan perlawanan tanah secara internal terhadap keruntuhan atau pergeseran tanah sepanjang bidang geser, dan tanah yang diberi beban akan membuat tegangan geser menahan keruntuhan tanah. Menurut Rustam dkk (2017), kekuatan geser tanah adalah sifat tanah yang sangat penting, di mana penggunaan kekuatan gesernya berhubungan dengan: (a) kapasitas daya dukung tanah, baik pondasi dangkal maupun pondasi dalam; (b) mobilisasi tekanan tanah lateral, baik tekanan tanah aktif aupun tekanan tanah pasif; dan (c) kestabilan lereng daerah galian dan timbunan. Bila tegangan geser sudah mencapai batas maksimal, maka akan terjadi keruntuhan dan pada bidang lereng akan terjadi longsor.

Purwanto dkk (2020), dalam penelitiannya melakukan pengujian sifat indeks tanah yang diambil dari daerah Pakjo Way Hitam, Palembang Kota, Provinsi Sumatera Selatan, dimana dari hasil pengujiannya adalah tanah lempung lunak, termasuk dalam sistem klasifikasi menurut USCS (Unified Soil Classification System) yaitu CH (clay) dan menurut AASHTO (American Association of State Highway and Transporting Official) yaitu A-7-6 (clavey soils). Dari hasil pengujian indeks properties, didapat tanah yang lolos saringan No. 200 lebih dari 82,56\% dan nilai batas cair (LL) lebih dari 66\%, dan hal ini menunjukkan bahwa tanah tersebut termasuk dalam tanah berbutir halus. Dengan kadar air

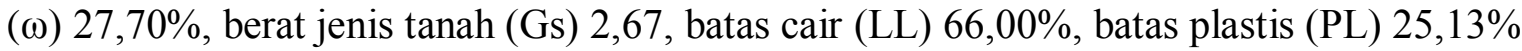
dan indeks plastis (IP) 40,87\%. Dan dari hasil pengujian pemadatan tanah standar diperoleh nilai kadar air optimum ( $1,74 \mathrm{gr} / \mathrm{cm}^{3}$. Rustam, dkk (2019) dalam penelitiannya menyimpulkan bahwa hasil indeks properti tanah merah / tanah lempung lunak di daerah Pakjo Palembang berdasarkan sistem klasifikasi USCS adalah lempung atau $\mathrm{CH}$, sedangkan berdasarkan sistem klasifikasi AASHTO adalah A-7-6. Dengan Indeks Plastisitas (IP) 40,87\%, Batas Cair 


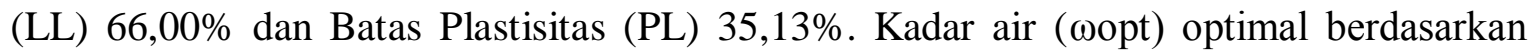
hasil standar Pengujian pemadatan tanah diperoleh kadar air optimum $22 \%$ dengan berat kering maksimum ( $\gamma \mathrm{dmax})$ 1,74 $\mathrm{gr} / \mathrm{cm}^{3}$. Dengan menggunakan limbah plafond, dari hasil uji geser langsung diperoleh nilai kohesi (c) sebesar 24,20 kPa (campuran limbah plafon gipsum persentase 15\%), nilai sudut geser dalam $(\phi)$ sebesar $15,15^{\circ}$ (campuran $15 \%$ limbah plafon gipsum ), dan nilai kuat geser $(\tau)$ sebesar $26,57 \mathrm{kPa}$ (pada campuran limbah plafon gipsum dengan persentase 15\%). Penelitian Sukmoyudho. dkk (2019) menyatakan bahwa bahwa dalam standar pemadatan dan uji perbaikan, campuran sabut kelapa yang ditambahkan ke tanah akan memperoleh nilai tertinggi dengan kadar serat $2 \%$ di bawah nilai kadar air $(\omega)$, dan mendapatkan nilai tertinggi pada berat kering $1 \%$. nilai $(\gamma \mathrm{d})$ dengan kandungan serat. Berdasarkan uji pemadatan yang ditingkatkan, nilai berat jenis kering $(\gamma \mathrm{d})$ di bawah 1\% kadar campuran adalah 1,609 $\mathrm{gr} / \mathrm{cm} 3$, yang hanya dapat digunakan sebagai timbunan biasa karena memenuhi persyaratan $\mathrm{MDD}=95 \%=1,52$ gr/cm3 Berdasarkan pengujian sabut kelapa karakteristik teknis campuran tanah dengan kadar 1\%, untuk mendapatkan nilai terbaik sebagai bahan timbunan Ramadhani (2011) melakukan penelitian kuat geser dengan campuran serat sabut tahan terhadap tanah berpasir. Hasil penelitian menunjukkan bahwa semakin besar persentase kandungan sabut kelapa dengan berat jenis relatif $0,25 \%$, kohesi tanah meningkat $0,0581 \mathrm{Kg} / \mathrm{cm} 2$, sedangkan gaya kohesif tanah tanpa sabut kelapa $0,0344 \mathrm{Kg} / \mathrm{cm} 2$, dan penambahan sabut kelapa Peningkatan 0,5\%, semakin besar kerapatan relatif, semakin rendah kohesi tanah. Untuk sudut gesek tanah, semakin tinggi persentase kandungan sabut kelapa antara $0,25 \%$ dan $0,5 \%$, semakin tinggi kerapatan relatifnya.Dibandingkan dengan sudut gesek tanah tanpa serat sabut kelapa yang hanya 28,17 , sudut gesekan tanah dengan serat sabut kelapan adalah 41,73. Dari hasil penelitian, karena penambahan 0,25\% dan 0,5\% sabut kelapa pada tanah berpasir maka nilai kuat gesernya menunjukkan kecenderungan meningkat seiring dengan meningkatnya kandungan sabut kelapa pada tanah berpasir Menurut Abdurrozak (2017), abu sekam padi adalah sisa pembakaran sekam padi (limbah sisa pembakaran sekam padi) dan berdasarkan penelitian sebelumnya menunjukkan bahwa abu sekam padi memiliki komponen kimia yang dapat digunakan untuk stabilisasi tanah, karena bahan kimia yang ada memiliki sifat pozzolan

Sehingga dari uraian di atas, tujuan dari penelitian ini adalah untuk mengetahui apakah campuran limbah sabut kelapa dan abu sekam padi dapat meningkatkan nilai kuat geser tanah merah melalui pengujian direct shear dengan persentanse penambahan sebesar $5 \%, 10 \%, 15 \%, 20 \%, 25 \%$ dengan skala laboratorium. 


\section{METODE PENELITIAN}

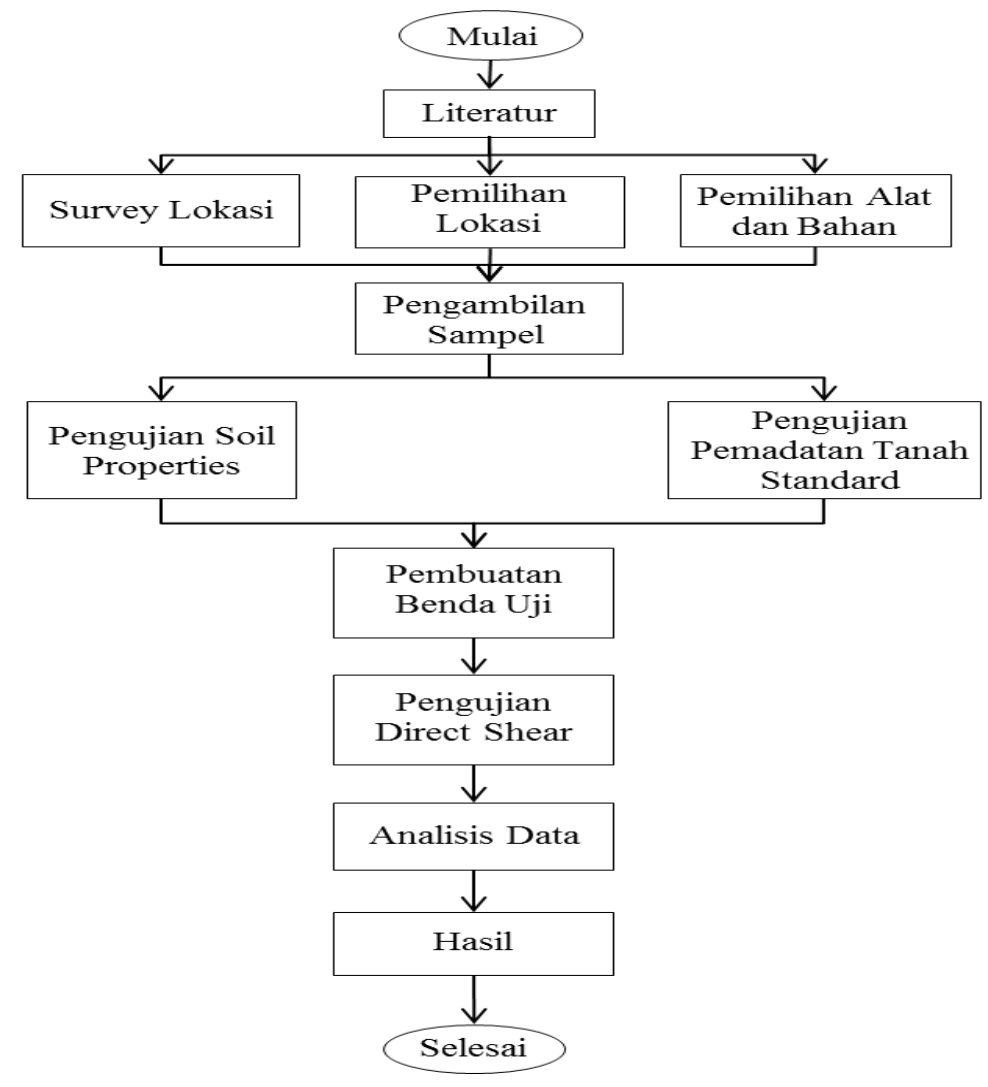

Gambar 1. Diagram Alir Penelitian

Diagram alir penelitian ditunjukkan pada Gambar 1. Titik lokasi sampel tanah diambil dengan alat bor tanah auger, dan kemudian sampel tanah dilakukan pengujian di laboratorium, yaitu pengujian soil propertis,pengujian pemadatan tanah standar dan pengujian Direct Shear. Pengujian soil propertis dimaksudkan guna mendapatkan kadar air $(\omega)$, berat jenis (Gs), batas cair (LL), batas plastis (PL), indeks plastisitas (IP) dan analis saringan butiran tanah. Dengan sistem klasifikasi tanah yang dipakai adalah standar USCS dan AASHTO. Kemudian dilakukan pengujian pemadatan tanah standar guna mendapatkan kadar air optimum dan berat isi kering optimum. Setelah sifat fisik diketahui, maka dilakukan pengujian Direct Shear (geser langsung) guna mendapatkan sudut geser dalam $(\phi)$ dan kohesi tanah (c)

Masing-masing sampel dibuat dengan penambahan sabut kelapa (SK) dan abu sekam padi (ASP) sebanyak 5\%, 10\%, 15\%, 20\% dan 25\%. Dimana tanah yang telah dikeringkan dan diayak di saringan nomor 4 kemudian dicampur dengan sabut kelapa dan abu sekam padi dengan komposisi sebagai berikut : (1) kondisi 5\% campuran digunakan tanah merah $1,9 \mathrm{~kg}$ dan SK+ASK 0,1 kg, (2) kondisi 10\% campuran digunakan tanah merah 1,8 kg dan SK+ASK 0,2 kg, (3) kondisi 15\% campuran digunakan tanah merah 1,7 kg dan SK+ASK $0,3 \mathrm{~kg}$, (4) kondisi $20 \%$ campuran digunakan tanah merah 1,6 kg dan SK+ASK 0,4 kg, (5) kondisi $25 \%$ campuran digunakan tanah merah $1,5 \mathrm{~kg}$ dan SK+ASK 0,5 kg. Dan selanjutnya dilakukan pengujian Direct Shear dengan beban $2,5 \mathrm{~kg}, 5 \mathrm{~kg}$ dan $10 \mathrm{~kg}$ 


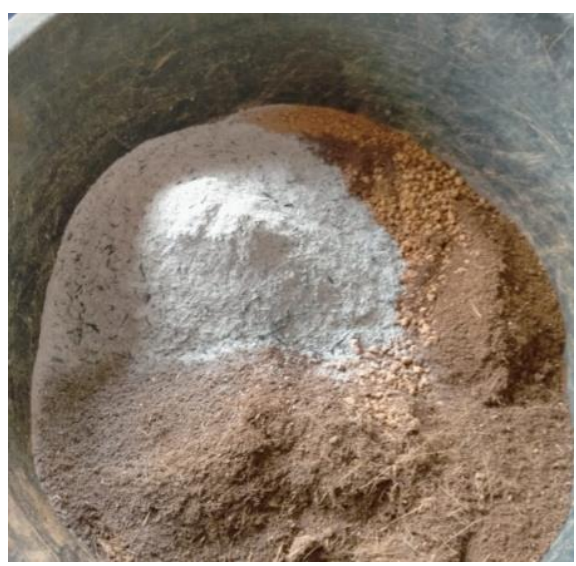

Gambar 2. Campuran Sabut Kelapa dan Abu Sekam Padi

\section{HASIL DAN PEMBAHASAN}

\section{Pengujian soil properties dan klasifikasi tanah}

Pengujian soil properties dilakukan untuk karakteristik sifak fisik tanah daerah Pakjo Palembang yang berupa kadar air ( $\omega)$, berat jenis (Gs), batas cair (LL), batas plastis (PL), indeks plastisitas (IP) dan analis saringan butiran tanah, sedangkan klasifikasi tanah dimasudkan untuk menentukan jenis tanah yang ada. Dari hasilk pengujian dan klasifikasi tanah didapat hasil ebagai berikut : kadar air asli $(\omega)=27,70 \%$, berat jenis tanah $(\mathrm{Gs})=$ 2,67, tanah lolos saringan nomor $4(0,425 \mathrm{~mm})=94,48 \%$, tanah lolos saringan nomor 200 $(0,075 \mathrm{~mm})=82,56 \%$, batas cair $(\mathrm{LL})=63,35 \%$, batas plastis $(\mathrm{PL})=25,13 \%$, indeks plastisitas $(\mathrm{IP})=38,22 \%$, klasifikasi tanah menurut AASHTO $=$ A-7-6 dan klasifikasi tanah menurut $\mathrm{USCS}=\mathrm{CH}$.

\section{Pengujian Pemadatan Tanah Standar.}

Pengujian ini dilakukan untuk mengetahui kadar air optimum dan berat isi kering optimum tanah, ditunjukkan pada gambar 1 berikut yang menunjukkan bahwa kadar air

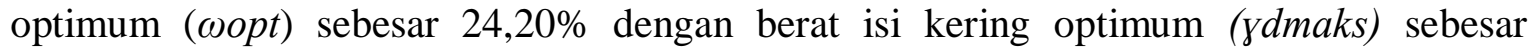
$1,634 . \mathrm{gr} / \mathrm{cm}^{3}$

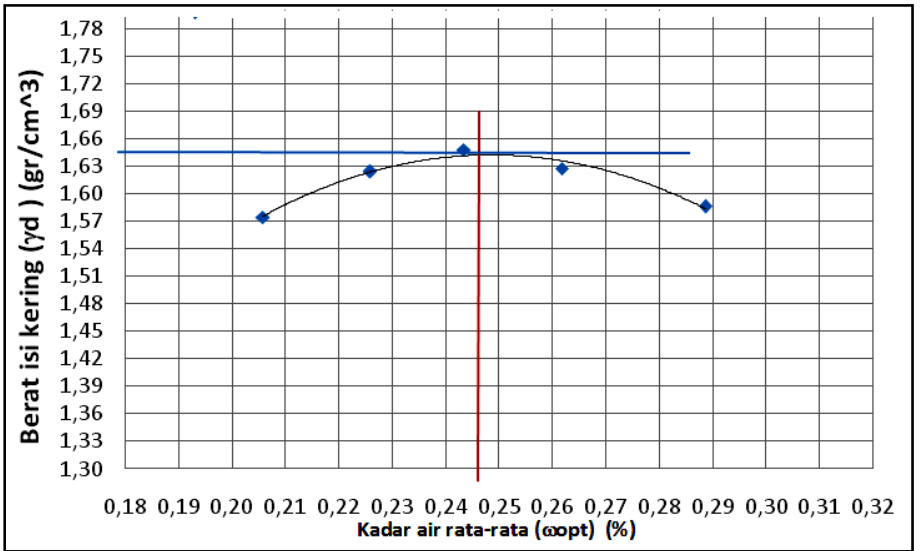

Gambar 1. Grafik Pemadatan Tanah Standard 


\section{Pengujian Kuat Geser Langsung (Direct Shear)}

Pengujian Direct Shear dilakukan untuk mengetahui nilai kohesi (c), nilai sudut geser dalam $(\phi)$ dan nilai kuat geser $(\tau)$. Hasil pengujian nilai kohesi (c) seperti tabel dan gambar berikut :

Tabel 1. Nilai Kohesi (c)

\begin{tabular}{|c|c|c|c|c|}
\hline \multirow{2}{*}{ Kode } & \multicolumn{3}{|c|}{ Nilai Kohesi c (kPa) } & \multirow{2}{*}{ Rata-rata } \\
\cline { 2 - 4 } & 1 & 2 & 3 & \\
\hline Tanah Merah Asli & 28,92 & 27,36 & 29,90 & 28,73 \\
\hline SK+ASP 5 \% & 63,45 & 66,05 & 44,46 & 57,98 \\
\hline SK+ASP 10 \% & 42,80 & 58,84 & 62,80 & 58,81 \\
\hline SK+ASP 15 \% & 43,08 & 42,87 & 57,49 & 47,81 \\
\hline SK+ASP 20 \% & 9,19 & 4,98 & 48,07 & 20,74 \\
\hline SK+ASP 25 \% & 51,44 & 32,08 & 18,54 & 34,02 \\
\hline
\end{tabular}

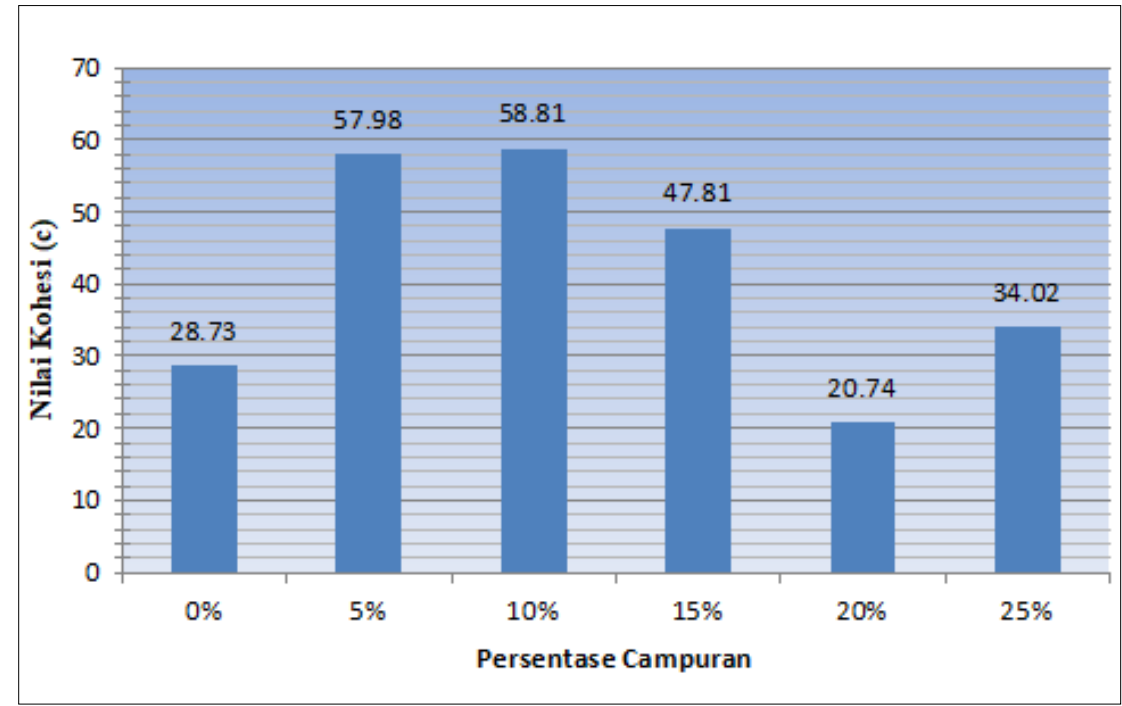

Gambar 2. Grafik Nilai Kohesi (c)

Dari grafik diatas nilai kohesi (c) tertinggi pada penambahan campuran sabut kelapa dan abu sekam padi sebanyak $10 \%$ dengan nilai $58,81 \mathrm{kPa}$

Hasil pengujian untuk nilai sudut geser dalam $(\phi)$ seperti tabel dan gambar berikut :

Tabel 2. Nilai Sudut Geser Dalam $(\phi)$

\begin{tabular}{|c|c|c|c|c|}
\hline \multirow{2}{*}{ Kode } & \multicolumn{3}{|c|}{ Nilai sudut geser dalam $\phi$} & \multirow{2}{*}{ Rata-rata } \\
\cline { 2 - 4 } & 1 & 2 & 3 & \\
\hline Tanah Merah Asli & 60,04 & 62,73 & 59,06 & 60,61 \\
\hline SK+ASP 5 \% & 17,78 & 51,43 & 66,91 & 45,37 \\
\hline SK+ASP10 \% & 59,69 & 47,01 & 41,71 & 49,47 \\
\hline SK+ASP 15 \% & 52,72 & 38,14 & 22,70 & 37,85 \\
\hline SK+ASP 20 \% & 78,02 & 62,94 & 32,23 & 57,73 \\
\hline SK+ASP 25 \% & 29,92 & 51,93 & 59,33 & 47,06 \\
\hline
\end{tabular}




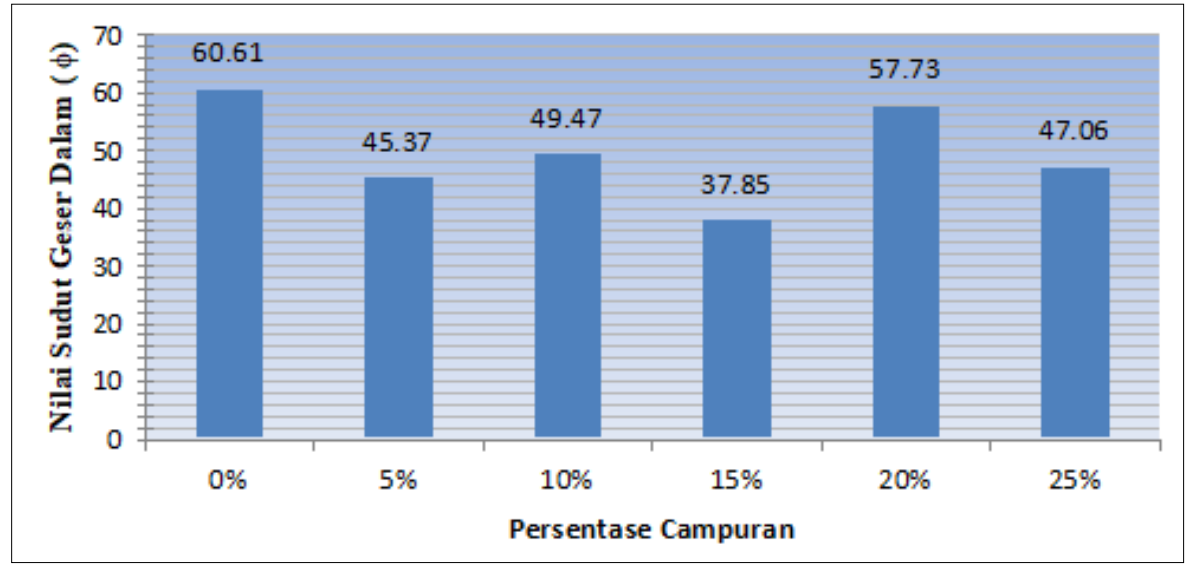

Gambar 3. Grafik Sudut Geser Dalam $(\phi)$

Dari grafik diatas nilai sudut geser dalam $(\phi)$ tertinggi pada penambahan campuran sabut kelapa dan abu sekam padi sebanyak $20 \%$ dengan nilai $57,73^{\circ}$

Hasil pengujian Direct Shear untuk nilai nilai kuat geser $(\tau)$ seperti tabel dan gambar berikut :

Tabel 3. Nilai Kuat Geser $(\tau)$

\begin{tabular}{|c|c|c|c|c|}
\hline \multirow{2}{*}{ Kode } & \multicolumn{3}{|c|}{ Nilai kuat geser dalam $\tau$} & \multirow{2}{*}{ Rata-rata } \\
\cline { 2 - 4 } & 1 & 2 & 3 & \\
\hline Tanah Merah Asli & 43,87 & 61,01 & 87,80 & 64,23 \\
\hline SK+ASP 5 \% & 66,22 & 87,81 & 147,48 & 100,5 \\
\hline SK+ASP 10 \% & 57,54 & 77,45 & 31,00 & 55,33 \\
\hline SK+ASP 15 \% & 54,40 & 56,50 & 72,02 & 60,97 \\
\hline SK+ASP 20 \% & 49,85 & 38,95 & 69,96 & 52,92 \\
\hline SK+ASP 25 \% & 56,21 & 54,24 & 77,07 & 62,51 \\
\hline
\end{tabular}

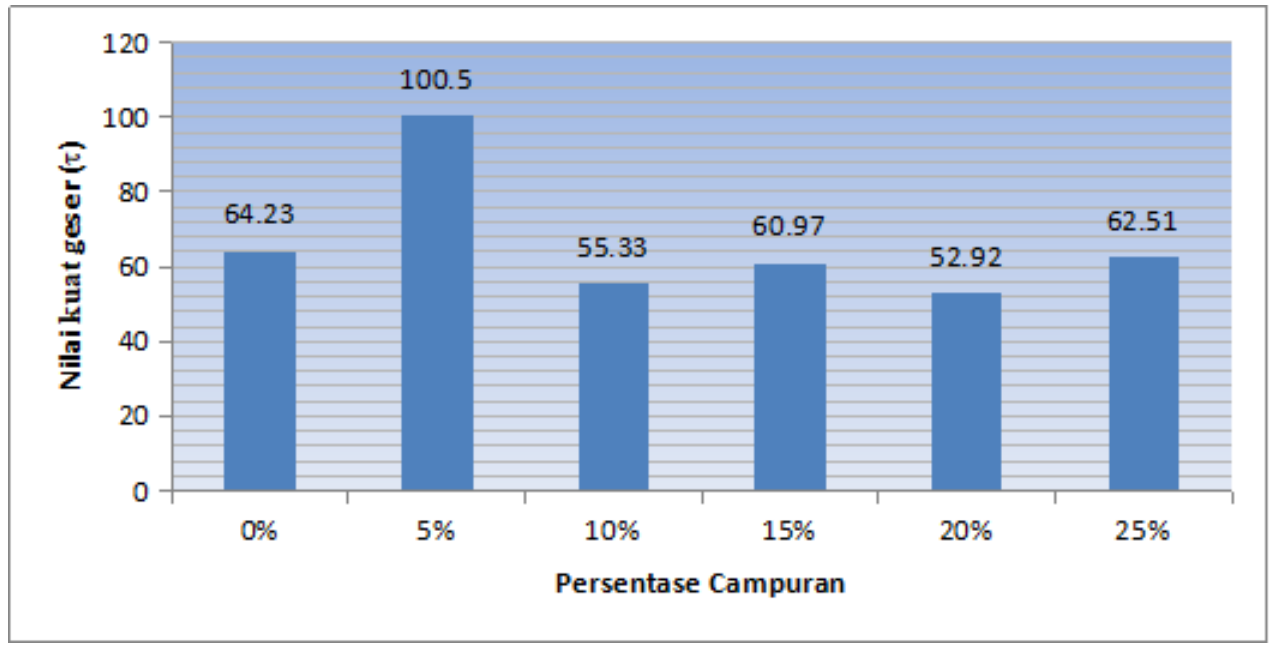

Gambar 4. Grafik Kuat Geser $(\tau)$

Dari grafik diatas nilai kuat geser $(\tau)$ tertinggi pada penambahan campuran sabut kelapa dan abu sekam padi sebanyak $5 \%$ dengan nilai $100,50 \mathrm{kPa}$ 
Dari gambar 2 diatas, nilai kohesi (c) terlihat bahwa pada campuran sabut kelapa dan abu sekam padi $10 \%$ mengalami kenaikan $(58,81 \mathrm{kPa})$, dan pada campuran $20 \%$ mengalami penurunan $(20,74 \mathrm{kPa})$. Pada gambar 3, terlihat bahwa nilai sudut geser dalam (ф) campuran sabut kelapa dan abu sekam padi $15 \%$ mengalami penurunan $\left(37,85^{\circ}\right)$, karena tanah mengalami pergeseran. Pada gambar 4 terlihat bahwa campuran sabut kelapa dan abu sekam padi $5 \%$ mengalami kenaikan $(100,50 \mathrm{kPa})$, karena sabut kelapa dan abu sekam padi mengikat tanah bermateri organik terhadap lempung dan sebaliknya pada campuran $20 \%$ mengalami penurunan $(52,92 \mathrm{kPa})$.

Pada penelitian sebelumnya yang menggunakan limbah plafond sebagai bahan campuran tanah, didapat hasil nilai kohesi (c) $24,20 \mathrm{kPa}$ pada campuran limbah plafond $15 \%$, nilai sudut geser dalam $(\phi)$ sebesar $15,15^{\circ}$ pada campuran $15 \%$, dan nilai kuat geser $(\tau)$ sebesar $26,57 \mathrm{kPa}$ pada campuran $15 \%$.

\section{KESIMPULAN}

Dari penelitian didapat sebagai berikut :

1. Hasil pengujian soil properties, tanah merah daerah Pakjo Palembang memiliki kadar air asli $(\omega)$ 27,70 \%, berat jenis tanah (Gs) 2,67, batas cair (LL) 63,35\%, batas plastis (PL) 25,13\% dan indeks plastisitas (IP) sebesar 38,22\%. Klasifikasi tanah menurut sistem USCS adalah $\mathrm{CH}$ atau tanah lempung dan menurut sistem AASHTO adalah A7-6 (clavey soils).

2. Hasil pengujian pemadatan tanah standar didapat kadar air optimum sebesar $24,20 \%$ dengan berat isi kering optimum sebesar $1,634 \mathrm{gr} / \mathrm{cm}^{3}$

3. Hasil pengujian Direct Shear, tanah merah ditambah dengan sabut kelapa dan abu sekam padi sebesa 5\% meningkatkan kuat geser tanah merah sebesar 100,50 kPa dengan nilai kohesi (c) $57,98 \mathrm{kPa}$ dan nilai sudut geser dalam $(\phi) 45,37^{\circ}$

\section{DAFTAR PUSTAKA}

Abdurrozak, M. R. (2017). Stabilisasi tanah lempung dengan bahan tambah abu sekam padi dan kapur pada subgrade perkerasan jalan. Teknisia, 22(2), 416-424.

Das, Braja M. 1995. “Mekanika Tanah 1”. Erlangga, Jakarta.

Das, B., M., (2008). Mekanika Tanah 1. Erlangga, Jakarta

Jimmyanto, H. (2014). Pengaruh Sampah Plastik dan Abu Sekam Padi Terhadap Kuat Geser Tanah Lempung Lunak (Doctoral dissertation, Sriwijaya University).

Jurnal, R. T. (2018). Studi Sifat Mekanis Tanah Merah dengan Pengujian Triaksial. In Jurnal Forum Mekanika (Vol. 7, No. 1, pp. 29-34).

Purwanto, H., Setiobudi, A., \& Rustam, R. K. (2020). Stabilization of soft clay soil using a gypsum plafond waste based on CBR testing. Int. J. Sci. Technol. Res, 9(2), 963968.

Ramadhani, S. (2011). Pengaruh penambahan serat sabut kelapa terhadap parameter kuat geser tanah berpasir. SMARTek, 9(3). 
Rustam, R. K., \& Amiwarti, A. (2017). Karakteristik Kuat Geser Tanah Merah. Simposium II UNIID 2017, 2(1), 394-399

Rustam, R. K., Purwanto, H., Adiguna, A., \& Putri, I. T. (2020). Pengaruh Penambahan Abu Arang Tempurung Kelapa Terhadap Kuat Geser Tanah Lempung di Daerah Makarti Jaya. Jurnal Deformasi, 4(2), 86-95.

Rustam, R. K., Resti, A., Purwanto, H., \& Muhammad, F. (2019). The effect of gypsum plafond waste on shear strength of soft clay soil. In IOP Conference Series: Materials Science and Engineering (Vol. 620, No. 1, p. 012039). IOP Publishing

Sukmoyudho, N. S., Priskasari, E., \& Eri Ardian, Y. (2019). Penambahan Serat Sabut Kelapa Sebagai Alternatif Bahan Campuran Untuk Memperkuat Timbunan Tanah Lempung. SONDIR, 3(1), 1-6.

Utami, Y. F. (2014). Pengaruh Penambahan Limbah Serat Karung Plastik Terhadap Daya Dukung Tanah Merah (Doctoral dissertation, Universitas Pendidikan Indonesia). 